\title{
Anti-fouling Paints Based on Extracts of Marine Organisms from the Colombian Caribbean
}

Pinturas antiincrustantes a base de extractos de organismos marinos del caribe colombiano

\begin{abstract}
G. Blustein ${ }^{8}$

Habitually, control of biological fouling includes application of paints containing toxic substances that end up contaminating marine ecosystem. Many organisms prevent settlement of other species synthesizing secondary metabolites that could be used in the elaboration of environmentally friendly anti-fouling paints. This work evaluated the behavior of anti-fouling paints based on extracts from marine invertebrates in the Colombian Caribbean: Agelas tubulata, Myrmekioderma gyroderma, Oceanapia peltata, Aplysina lacunosa, Neopetrosia próxima, and Holothuria glaberrima. The painted panels were submerged in the port of Mar del Plata (Argentina); after 90 days in the sea significant differences were registered in the total coverage between the painted panels and the controls $(\mathrm{p}<0.05)$. The results obtained represent important progress toward using natural compounds in controlling encrustations.
\end{abstract}

C. Puentes ${ }^{1}$

K. Carreño ${ }^{2}$

M. Santos-Acevedo ${ }^{3}$

J. Gómez-León ${ }^{4}$

M. García 5

M. Pérez ${ }^{6}$

M. Stupak ${ }^{7}$

Key words: biofouling, sponges, sea cucumbers, anti-fouling paints.

\section{Resumen}

Habitualmente, el control de las incrustaciones biológicas incluye la aplicación de pinturas que contienen sustancias tóxicas que resultan contaminantes para el ecosistema marino. Muchos organismos previenen el asentamiento de otras especies sintetizando metabolitos secundarios que podrían utilizarse en la elaboración de pinturas antiincrustantes amigables con el medio ambiente. En este trabajo se evaluó el comportamiento de pinturas antifouling a base de extractos de invertebrados marinos del Caribe Colombiano: Agelas tubulata, Myrmekioderma gyroderma, Oceanapia peltata, Aplysina lacunosa, Neopetrosia proxima y Holothuria glaberrima. Los paneles pintados se sumergieron en el puerto de Mar del Plata (Argentina); luego de 90 días en el mar se registraron diferencias significativas en la cobertura total entre los paneles pintados y los controles $(\mathrm{p}<0,05)$. Los resultados obtenidos representan un avance importante hacia la utilización de compuestos naturales en el control de las incrustaciones.

Palabras claves: biofouling, esponjas, pepinos de mar, pinturas antifouling.

Date Received: March 31th, 2014 - Fecha de recepción: 31 de Marzo de 2014

Date Accepted: May 18th, 2014 - Fecha de aceptación: 18 de Mayo de 2014

${ }^{1}$ Tesista. Instituto de Investigaciones Marinas y Costeras (INVEMAR). Santa Marta - Colombia. e-mail: carlos.puentes@invemar.org.co

${ }^{2}$ Tesista. Instituto de Investigaciones Marinas y Costeras (INVEMAR). Santa Marta - Colombia. e-mail: katerine.carreno@invemar.org.co

${ }^{3}$ Investigador. Instituto de Investigaciones Marinas y Costeras (INVEMAR). Santa Marta - Colombia. e-mail: msantos@invemar.org.co

${ }^{4}$ Investigador. Instituto de Investigaciones Marinas y Costeras (INVEMAR). Santa Marta - Colombia. e-mail: jgomezleon@invemar.org.co

${ }^{5}$ Profesional CICPBA. Centro de Investigación y Desarrollo en Tecnología de Pinturas (CIDEPINT). La Plata - Argentina. e-mail: biofouling@cidepint.gov.ar

${ }^{6}$ Profesional CONICET. Centro de Investigación y Desarrollo en Tecnología de Pinturas (CIDEPINT). La Plata - Argentina; Universidad Nacional de La Plata.

La Plata - Argentina. e-mail: biofouling@cidepint.gov.ar

${ }^{7}$ Profesional CONICET. Centro de Investigación y Desarrollo en Tecnología de Pinturas (CIDEPINT). La Plata - Argentina. e-mail: biofouling@cidepint.gov.ar

${ }^{8}$ Investigador CONICET. Centro de Investigación y Desarrollo en Tecnología de Pinturas (CIDEPINT). La Plata - Argentina; Profesor. Universidad Nacional de La Plata. La Plata - Argentina. e-mail: antifouling@cidepint.gov.ar 


\section{Introduction}

Biofouling is known as the attachment and growth of micro and/or macroorganisms on any natural or artificial submerged substrate. The formation of biofouling is a process that implies a series of stages that lead to the consolidation of a community of encrusting organisms subject to changes in function of the prevailing conditions in the system. One of the most widely accepted approaches considers this process formed by distinct phases that include biochemical conditioning of the surface followed by settlement and growth of pioneer bacteria, unicellular organisms, and late-stage prokaryotes (microfouling) and, finally, development of macroscopic organisms (macrofouling) (Wahl, 1989; Railkin, 2003; Chambers et al., 2006).

Marine biofouling seriously affects submerged structures (ships, platforms, buoys, culture farms, etc.) causing big economic losses of diverse nature. Particularly, attachment on hulls of vessels implies an increase between 40 and 50\% in fuel consumption due to increased motion resistance (IMO- International Maritime Organization, 2002); in turn, settlement of organisms favors corrosion processes, generating high costs related to cleaning, removal, fairing, and repainting requiring millions of dollars yearly throughout the world. When the bottoms of vessels are not protected by antifouling systems they can accumulate up to 150 $\mathrm{kg}$ of biofouling per square meter in less than six months in the sea, which is why it is necessary to use effective methods for its control (Callow and Callow, 2003).

Use of anti-fouling paints is the most efficient method to control biofouling. The action mechanism of these paints is based on the controlled release of or pigments that contain generating a highly toxic interface that avoids attachment of organisms (Caprari and Lecot, 2001). Anti-fouling paints have very particular characteristics that, due to their mode of action, are totally differentiated from the other types known; the paint film modifies permanently its characteristics when it is submerged, with the fundamental objective being that of achieving adequate solubilization de toxic. The toxic loss has a critical minimum value that depends on the toxic used and on the paint formulation; below said value, the paint has no preventive action.

The initial solubilization of the biocide (initial leaching rate) is generally high, given that it results from excess toxics accumulated in the paint film. This value is important because the paint must start to act immediately after the immersion and the effectiveness will depend on the solubility of the toxic, on the characteristics of the vehicle, on the surface area of toxic particles, and on the conditions of temperature, salinity, and $\mathrm{pH}$ of the water. After several days of immersion, a constant leaching rate is reached.

During the last four decades, antifouling pigments have been used of excellent biocide power but highly contaminating and harmful to the biota. Among these, there are mercuric oxide $(\mathrm{HgO})$, mercuric arsenate $\left(\mathrm{AsO}_{4} \mathrm{Hg}_{3}\right)$, arsenic trioxide $\left(\mathrm{As}_{2} \mathrm{O}_{3}\right)$, cuprous arsenite $\left(\mathrm{AsO}_{3} \mathrm{Cu}_{3}\right)$, and organometallic substances; mainly tributyltin oxide (TBTO) and triphenyl tin oxide (TPTF). However, research conducted fundamentally in the northern hemisphere confirmed the impact of organoarsenic compounds added to paints on marine life; among these, deformation of shells and imposex phenomena in oyster populations (Bettin et al., 1996; Pereira et al., 1999; Wu et al., 2010), immune responses, neuro-toxic and genetic affections in fishes (IMO, 2002; Ferraro et al., 2004) and bio-accumulation in mammals (Yebra et al., 2004). As a consequence of these results, as of 1991, strict regulations were established for the use of this substance in many countries, later resulting in legislation that culminated in the total prohibition of the application of antifouling paints based on TBT since the start of 2003 and the prohibition of their manufacture as of 2008 (Chambers et al., 2006). By virtue of these restrictions, possible replacements have been developed like Irgarol $1051^{\circ}$, Sea-Nine $211^{\circ}$, chlorothalonil, dichlofluanid, tolylfluanid, and zinc pyrithiona (Voulvoulis et al., 1999; Konstantinou and Albanis, 2004; Bellas, 2005). However, these compounds have been found in relatively high concentrations in ports, marinas, and coastal zones (Martinez et al., 2001; 
Voulvoulis et al., 2000; Voulvoulis et al., 2002; Reitsema, 2008).

Biofouling is known as the attachment and growth of micro and/or macroorganisms on any natural or artificial submerged substrate. The formation of biofouling is a process that implies a series of stages that lead to the consolidation of a community of encrusting organisms subject to changes in function of the prevailing conditions in the system. One of the most widely accepted approaches considers this process formed by distinct phases that include biochemical conditioning of the surface followed by settlement and growth of pioneer bacteria, unicellular organisms, and late-stage prokaryotes (microfouling) and, finally, development of macroscopic organisms (macrofouling) (Wahl, 1989; Railkin, 2003; Chambers et al., 2006).

Marine biofouling seriously affects submerged structures (ships, platforms, buoys, culture farms, etc.) causing big economic losses of diverse nature. Particularly, attachment on hulls of vessels implies an increase between 40 and 50\% in fuel consumption due to increased motion resistance (IMO- International Maritime Organization, 2002); in turn, settlement of organisms favors corrosion processes, generating high costs related to cleaning, removal, fairing, and repainting requiring millions of dollars yearly throughout the world. When the bottoms of vessels are not protected by antifouling systems they can accumulate up to 150 $\mathrm{kg}$ of biofouling per square meter in less than six months in the sea, which is why it is necessary to use effective methods for its control (Callow and Callow, 2003).

Use of anti-fouling paints is the most efficient method to control biofouling. The action mechanism of these paints is based on the controlled release of or pigments that contain generating a highly toxic interface that avoids attachment of organisms (Caprari and Lecot, 2001). Anti-fouling paints have very particular characteristics that, due to their mode of action, are totally differentiated from the other types known; the paint film modifies permanently its characteristics when it is submerged, with the fundamental objective being that of achieving adequate solubilization de toxic. The toxic loss has a critical minimum value that depends on the toxic used and on the paint formulation; below said value, the paint has no preventive action.

The initial solubilization of the biocide (initial leaching rate) is generally high, given that it results from excess toxics accumulated in the paint film. This value is important because the paint must start to act immediately after the immersion and the effectiveness will depend on the solubility of the toxic, on the characteristics of the vehicle, on the surface area of toxic particles, and on the conditions of temperature, salinity, and $\mathrm{pH}$ of the water. After several days of immersion, a constant leaching rate is reached.

During the last four decades, antifouling pigments have been used of excellent biocide power but highly contaminating and harmful to the biota. Among these, there are mercuric oxide $(\mathrm{HgO})$, mercuric arsenate $\left(\mathrm{AsO}_{4} \mathrm{Hg}_{3}\right)$, arsenic trioxide $\left(\mathrm{As}_{2} \mathrm{O}_{3}\right)$, cuprous arsenite $\left(\mathrm{AsO}_{3} \mathrm{Cu}_{3}\right)$, and organometallic substances; mainly tributyltin oxide (TBTO) and triphenyl tin oxide (TPTF). However, research conducted fundamentally in the northern hemisphere confirmed the impact of organoarsenic compounds added to paints on marine life; among these, deformation of shells and imposex phenomena in oyster populations (Bettin et al., 1996; Pereira et al., 1999; Wu et al., 2010), immune responses, neuro-toxic and genetic affections in fishes (IMO, 2002; Ferraro et al., 2004) and bio-accumulation in mammals (Yebra et al., 2004). As a consequence of these results, as of 1991, strict regulations were established for the use of this substance in many countries, later resulting in legislation that culminated in the total prohibition of the application of anti-fouling paints based on TBT since the start of 2003 and the prohibition of their manufacture as of 2008 (Chambers et al., 2006). By virtue of these restrictions, possible replacements have been developed like Irgarol $1051^{\circ}$, Sea-Nine $211^{\circ}$, chlorothalonil, dichlofluanid, tolylfluanid, and zinc pyrithiona (Voulvoulis et al., 1999; Konstantinou and Albanis, 2004; Bellas, 2005). However, these compounds have been found in relatively high concentrations in ports, marinas, and coastal zones (Martínez et 
al., 2001; Voulvoulis et al., 2000; Voulvoulis et al., 2002; Reitsema, 2008).

Bearing in mind the aforementioned and due to the vast bioactive potential found in natural products obtained from marine organisms or which are synthesized by them, currently, studies are focused on optimizing methods that permit their incorporation onto anti-fouling paints.

The natural products are chemical entities synthesized by cells of plants, animals, and microorganisms that are not used in the primary metabolism, which has granted them the name of "secondary metabolites" (Pawlik, 2011). The functions of these metabolites are not as evident on the survival of the organisms as are the products of the primary metabolism; however, they play a fundamental ecological role in the development and survival of the species that synthesize those (Harper et al, 2001).

Currently, one of the most promising fields of search of natural products is that of marine organisms, given that they synthesize secondary metabolites that have proven to have great potential in the pharmaceutical, cosmetic, and agrochemical industries. Their potential has also been shown for development of molecular probes, enzyme technology, production of chemical precursors and nutritional supplements (Pomponi, 1999). Growing interest in substances produced by marine organisms is mainly because many of the compounds they produce are unique at structural level and have pharmacological properties (Jha and $Z i$-rong, 2004). This search for new natural products has resulted in the report of over 18,000 compounds isolated from 4,796 species from 24 different phyla, which is equivalent to $0.27 \%$ of the known species of marine organisms (Blunt et al., 2008).

Current research on the topic focuses on the search for environmentally friendly compounds. Emphasis has been made on identifying active principles existing in organisms that naturally do not present epibionts and which have not developed inhibition or repulsion mechanisms to protect their bodily surface (Harder, 2009) or rather in those that have developed chemical defenses against predators, which is why it is assumed that secondary metabolites are potential antifouling agents (Davis and Wright, 1989; Clare et al., 1992, Pawlik, 1992; Abarzua and Jakubowski, 1995; Clare, 1996; da Gama et al., 2002; Rao et al., 2007). The effect fouling provokes upon organisms is varied, numerous compounds act as anesthetics, others as repellents of the attachment or as inhibitors of the properties that determine the adhesion mechanisms without having biocide effects (Omae, 2003). However, although the antifouling action of these compounds has been widely proven, until now their incorporation onto paints has not been concrete.

This work evaluated the behavior of anti-fouling paints of soluble matrix based on extracts of marine invertebrates from the Colombian Caribbean, seeking to find environmentally friendly formulations with potential application on vessels and other submerged structures. For this, extracts were elaborated from Agelas tubulata, Myrmekioderma gyroderma, Oceanapia peltata, Aplysina lacunose, and Neopetrosia proxima sponges and from the Holothuria glaberrima sea cucumber.

\section{Methodology}

\section{Study area}

The study was developed near Santa Marta in the Colombian Caribbean and Mar del Plata in the Argentine Atlantic. The area for the collection of marine organisms includes different locations along the coastal zone of the Tourism, Cultural, and Historical District of Santa Marta, in the department of Magdalena to the north of the Colombian territory, between the bay of Neguange in the Tayrona Natural National Park and the beaches by the airport on the extreme south of the urban perimeter of the city of Santa Marta.

The study zone in Argentina is located in the port of Mar del Plata, province of Buenos Aires, situated to the south of Cabo Corrientes $\left(38^{\circ} 08^{\prime} \mathrm{S}-57^{\circ} 31^{\prime} \mathrm{W}\right)$. The sampling site used to carry out the experiences is the Club de Motonáutica located in the port. 


\section{Species evaluated}

The species studied were Agelas tubulata, Myrmekioderma gyroderma, Oceanapia peltata, Aplysina lacunosa, Neopetrosia proxima sponges and the Holothuria glaberrima sea cucumber.

The sponges belong to the Phylum Porifera and are fundamentally marine organisms, whose principal characteristic is multicellularity (they do not form true tissue). Their structure is constituted by pores and channels through which water currents flow used to carry out most of their functions. These are eminently sessile, filtering, and mostly asymmetric organisms; except for some less complex species with radial symmetry (Mille, 2008). Sea cucumbers, in turn, belong to the Phylum Echinodermata characterized for having a calcareous internal skeleton and complex organ systems.

\section{Agelas tubulata}

In the Agelas genus species are characterized for having styles with rows of spines with more or less regular spaces as the only type of spike present. A tubulata (Fig. 1) forms clusters that can exceed $20 \mathrm{~cm}$ heights, with tubular shape, apertures $5-8 \mathrm{~cm}$ in diameter, yellow-orange coloring, with a smooth surface and of elastic and compressible consistency (Lehnert and Soest, 1996). It is broadly distributed in the Caribbean, being reported in Belize, Cuba, Caiman Islands, Greater Antilles, and Venezuela (Lehnert and Soest, 1996; Miloslavich et al., 2010).

Fig. 1. A. tubulata

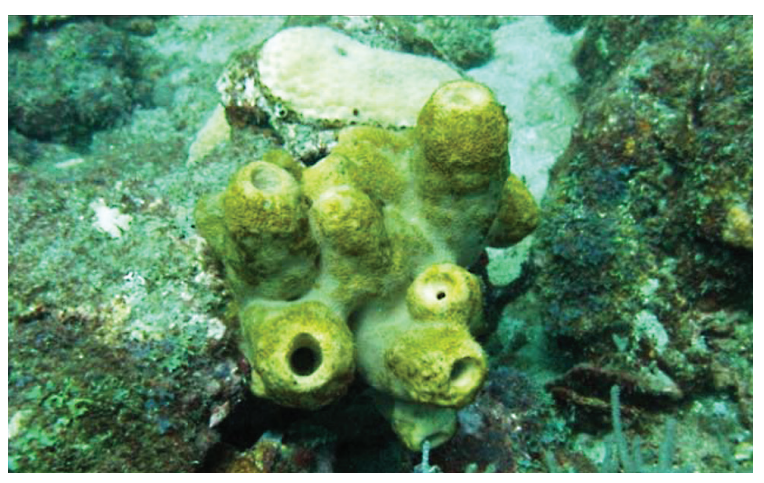

\section{Myrmekioderma gyroderma}

The Myrmekioderma genus is characterized for generating encrusting or massive formations, presenting a hispid surface, with characteristic excavated meanders, sinuous or straight channels, and grooves. On occasion, it forms tuberculated polygonal plates (Hooper, 2002). The $M$. gyroderma species (Fig. 2) may or may not present lobed or cushion shape, often reaching high thickness, with osculate $4-10 \mathrm{~cm}$ without determined position, with coloring from yellow to bright orange, of irregular surface and firm, elastic consistency and somewhat lumpy on touch (Alcolado, 1984). It has broad distribution throughout the Caribbean, Greater Antilles, Colombia, Panama, Gulf of Mexico (Alcolado, 1984; Miloslavich et al., 2010).

Fig. 2. M. gyroderma

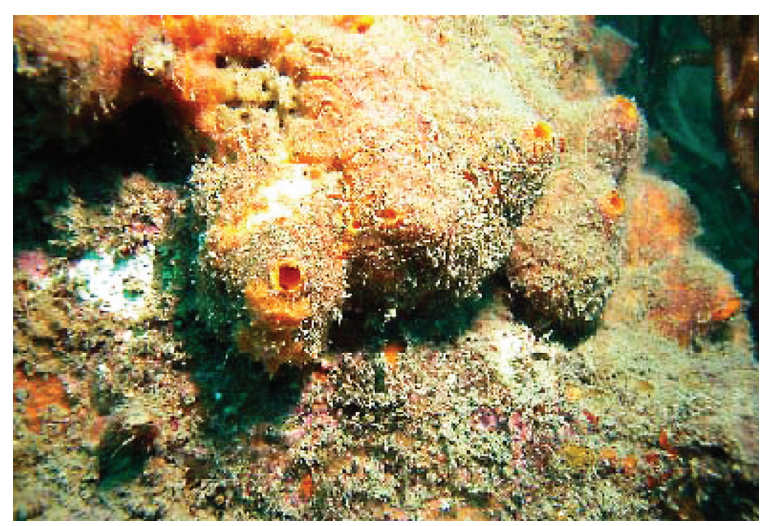

\section{Neopetrosia proxima}

The Neopetrosia genus includes compact species with a finely hispid surface, which is smooth and velvety on touch; of hard, rock-like consistency; of irregular sizes and shapes (DesqueyrouxFaundez and Valentine, 2002a). The N. proxima species (Fig. 3) is presented as encrustations, as fingerlike erect lobes with thickened apices, or flattened to sub-spherical masses. It has punctate, microhispid surface, in general full of detritus. Its coloring is commonly brown with light or dark purple or violet tones; unexposed sides and cream interior. The consistency is firm, hard, somewhat difficult to break and cut, exuding sticky mucus upon touch (Zea, 1987). It is distributed in Colombia (Urabá, Cartagena, and Santa Marta), Brazil, Puerto Rico, and the Virgin Islands (Zea, 1987). 
Fig. 3. N. proxima

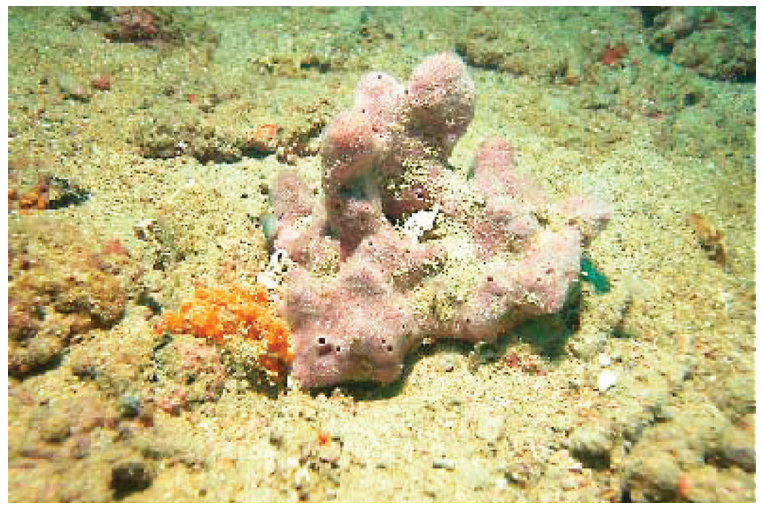

\section{Oceanapia peltata}

The Oceanapia genus is constituted by species of massive, globular, or lamellar form, with long tubular processes or fistulas, open or close in its ends (Desqueyroux-Faúndez and Valentine, 2002b). Oceanapia peltata is a massive globular species that is usually embedded in the sand; it has fistular cylindrical projections that protrude from the sand and have smooth ends or projections with pagoda form, with 2-4 $\mathrm{cm}$ width and $1 \mathrm{~mm}$ thickness, with cream or grayish color (Fig.4). The consistency of the body globule is slightly compressible and quite fibrous; also, the fistulas on touch are smooth, softer, and less fibrous (Collin et al., 2005). The species is registered at $50-100 \mathrm{~m}$ depths in Colombia, Florida, Cuba, and Bocas del Toro (Panamá) (Collin et al., 2005).

Fig. 4. Oceanapia peltata

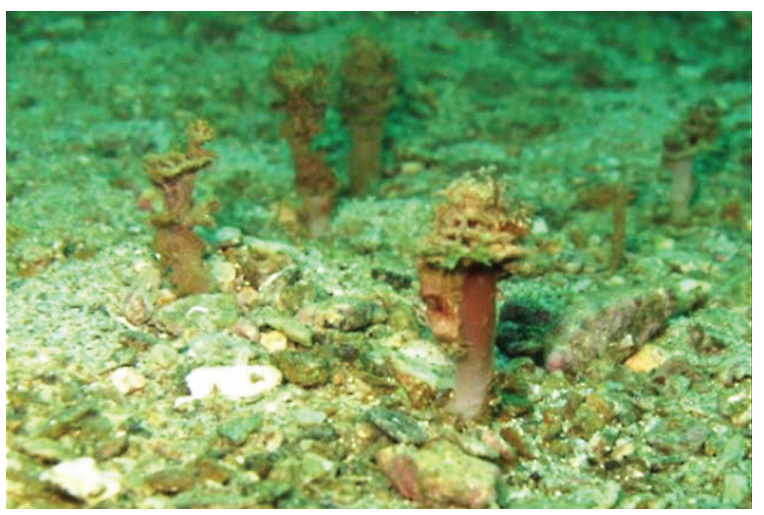

\section{Aplysina lacunosa}

The Aplysina genus is characterized by the presence of fibers of a single class, without exogenous detritus and by the presence of a thick medullar component. The fibers form a regular reticulum with large polygonal meshes without specialized surface arrangement (Bergquist and Cook, 2002). The A. lacunosa species (Fig. 5) forms solitary tubes or in groups of up to $50 \mathrm{~cm}$ in height and 4-10 $\mathrm{cm}$ of diameter. It has thick walls from 1.5 to $2.3 \mathrm{~cm}$ and above. It is a species of firm consistency, not very compressible and in very big specimens these are more flexible and soft (Zea, 1987). It is distributed in Colombia (Urabá, Cartagena, Santa Marta, and Providencia), the Bahamas, Florida, Jamaica, Puerto Rico, the Dominican Republic, Curaçao and Bonaire (Zea, 1987).

Fig. 5. A. lacunosa

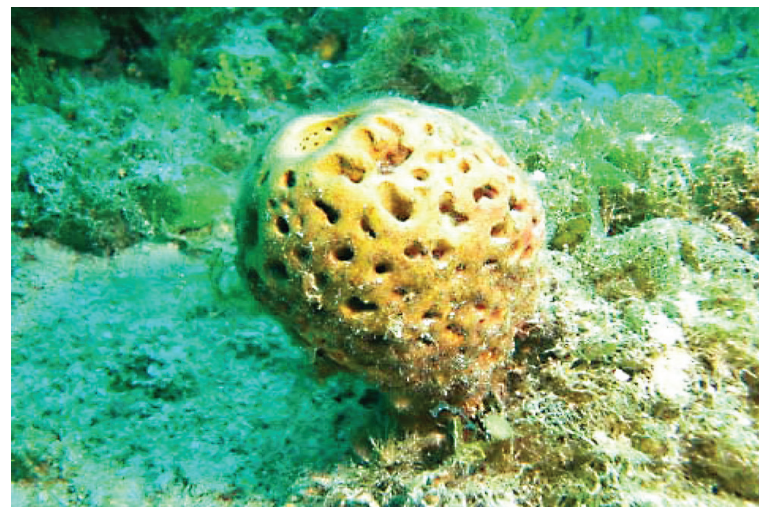

\section{Holothuria glaberrima}

This echinoderm species, Holothuria glaberrima Selenka, 1867, is small, reaches a maximum length of approximately $15 \mathrm{~cm}$; it has a cylindrical body with soft skin, numerous tube feet on the ventral surface also presenting small and inconspicuous dorsal papillae and long tentacles that are quite branched and dendritic (Fig. 6). They have gregarious habits and typically inhabit coastal areas of low tides, exposed to wave action (Lewis, 1960; Hendler et al., 1995). Their distribution extends to the south of the Bahamas and in the western Caribbean to Trinidad and in Colombia coasts (Tierra Bomba, Cartagena; Punta de la Loma, Santa Marta) to Mexico (Lewis, 1960; Caycedo, 1978; Hendler et al., 1995). 
Fig. 6. Holothuria glaberrima

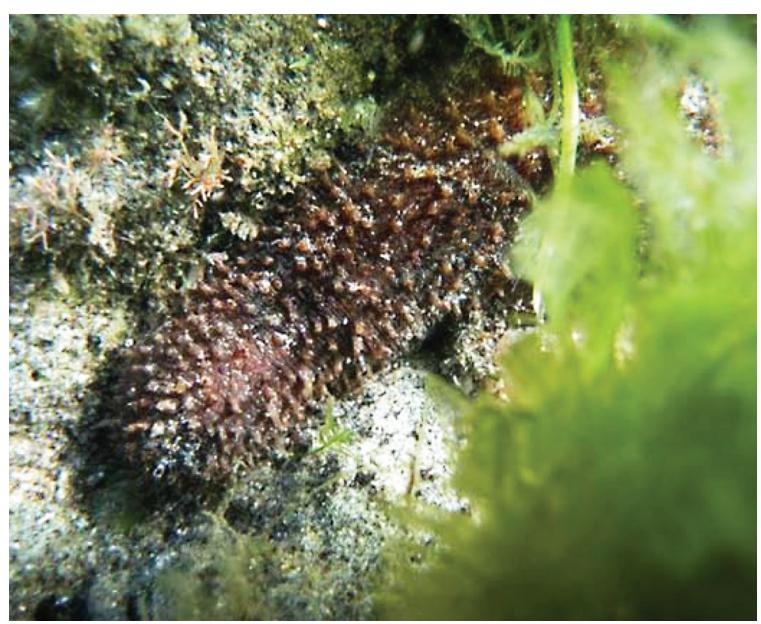

Processing of samples

The invertebrates studied were obtained through manual collection in natural substrates with autonomous diving equipment. Prior to the extraction process, the material is cleaned (removal of accompanying fauna and other elements); the tissue is cut into portions and deposited in jars and frozen at $-15{ }^{\circ} \mathrm{C}$. Thereafter, the samples are lyophilized between 36 and 48 hours at $-45^{\circ} \mathrm{C}$ and 0.120 mbar. The weight of the dry material obtained is recorded, followed by phase to obtain the extract.

Extraction of the metabolites present in the tissues of the organisms selected is carried out by using a methanol/dichloromethane mix (1:1) that permits the dissolution of a broad range of compounds according to the methodology used by Castellanos (2007). The dry tissue is subjected to extraction through maceration at room temperature $\left(20^{\circ} \mathrm{C}\right)$ during 24 hours by submerging it in the solvent mixture and maintaining continuous agitation at $120 \mathrm{rpm}$. After this time, gravity filtering is carried out by employing slightly compact degreased cotton as filter; the leftover tissue is again extracted under the same conditions until completing 72 hours of extraction, filtering every 24 hours. To obtain a mixture free of solvents, the solution resulting from each filtration is concentrated by using a rotavapor with a heating bath at $38{ }^{\circ} \mathrm{C}$; under pressure of $600 \mathrm{mbar}$ during one hour the dichloromethane is removed and at 100 mbar during three hours the methanol is removed. If necessary, the extract is lyophilized to bring the sample to complete dryness; lastly, the resulting material is decanted to a clean jar to register what will be denominated "total extract". A portion of the total extract is destined for the fractionating process according to the scheme shown in Fig. 7.

The portion of the extract denominated organic phase was reserved to prepare anti-fouling paints.

\section{Preparation of soluble matrix paints}

In soluble matrix paints, the toxic and the vehicle are solubilized jointly, with diminished film thickness. For the formulation of the vehicle rosin resin is used, which is the principal film forming material. Rosin resin is of natural origin; it is extracted from conifers and it is soluble or erosional by water. It is of acidic nature and composed of $90 \%$ resin acids, mainly abietic and levopimaric acid (Rascio et al., 1988). The free carboxyl groups $(-\mathrm{COOH})$ allow it to react with alkaline sea water $(\mathrm{pH} 8)$ forming soluble resinates and facilitating the release of the toxic substance. However, the colophony generates an excessively soluble film, which is not very adherent and brittle, which is why it is plasticized by incorporating oils or varnishes; its solubility in sea water is affected by the drying time (Rascio et al., 1977).

The paints were prepared at the CIDEPINT pilot plant (Argentina). For this, a porcelain ball mill was used constituted by a 1-1 capacity cylindrical container (jar) that rotates according to a horizontal axis on cylindrical bearings powered by a motor (Fig. 8). The porcelain jar used has an adjustable lid and it is loaded with the paint components. The dispersion is achieved fundamentally through the cascade effect produced by the motion of the spheres. The pigment particles are subjected to impact and shear effort (Giúdice, et al., 1980).

During a first stage, the ligand of the paint was elaborated by dissolving rosin resin and oleic acid (plasticizer) in a xylene/mineral turpentine mix in a high-speed disperser. The jar was loaded with the ligand and the pigments (zinc oxide and chalk) and these were dispersed for 24 hours. The 
Fig. 7.

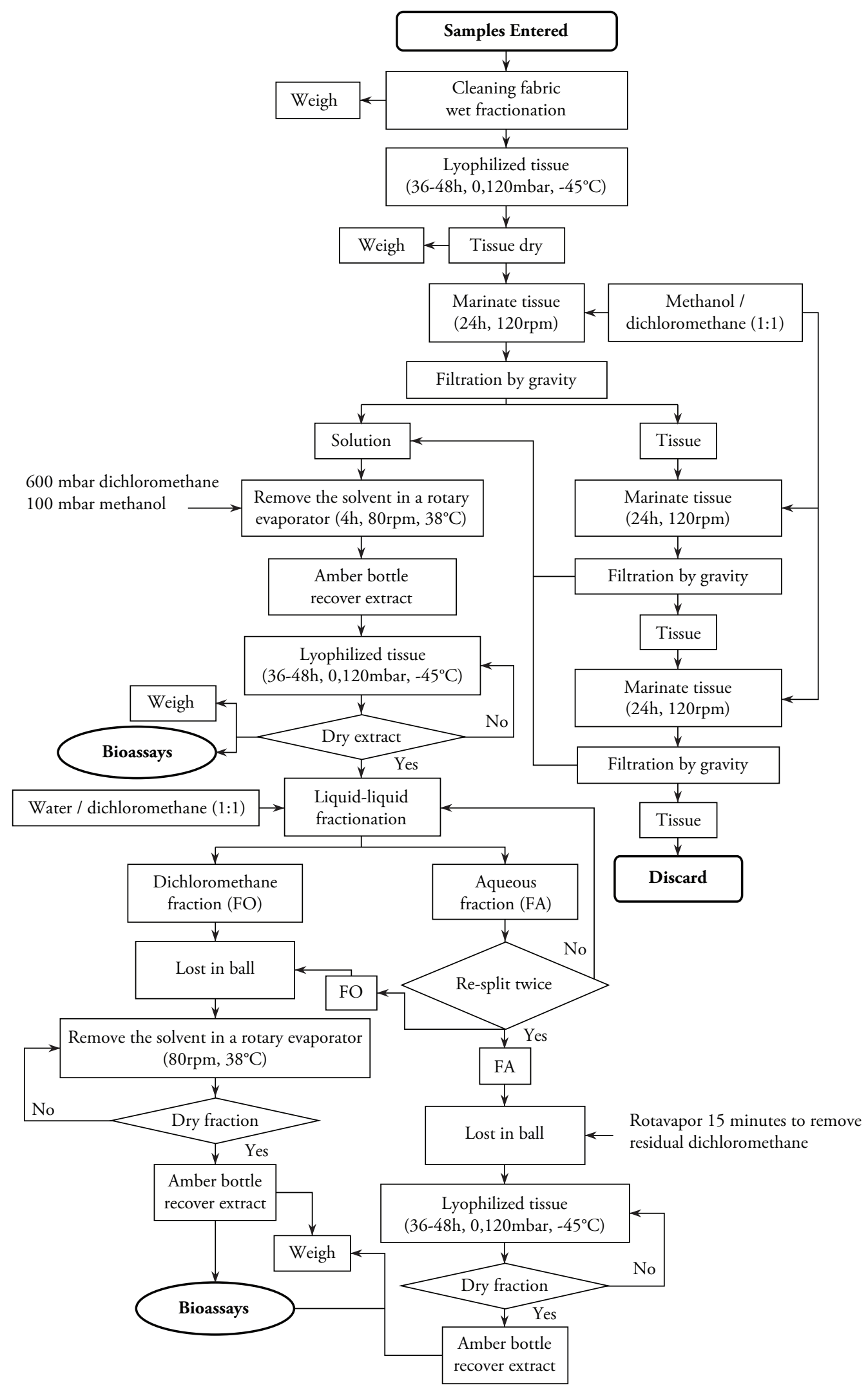


Fig. 8.

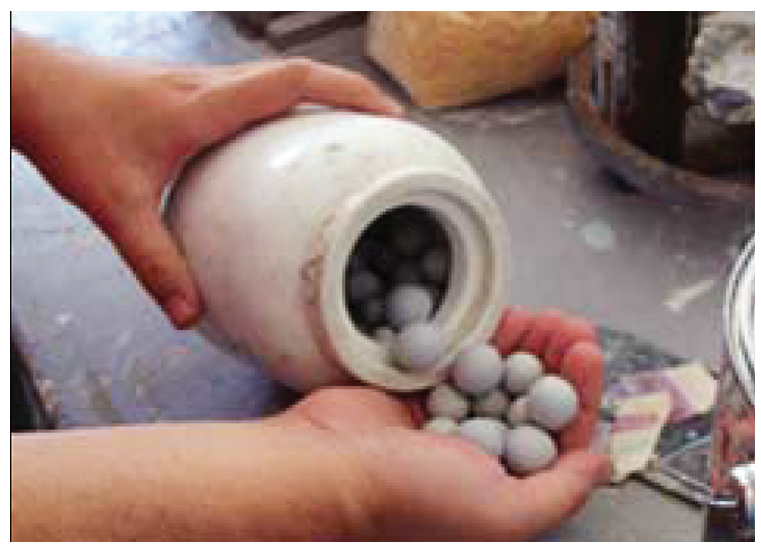

paint obtained was filtered and fractionated into seven portions; one of these was used as negative control (P1) and the remaining ones were added to the extracts (organic phase) dissolved in the same solvent mixture used for the paint (Tables 1 and 2).

Table 1. Composition of the paints

\begin{tabular}{lc}
\hline \multicolumn{1}{c}{ Components } & \% V/V \\
\hline Zinc oxide & 16.2 \\
\hline Chalk & 10.8 \\
\hline Rosin resin & 27.0 \\
\hline Oleic acid & 6.0 \\
\hline Xylene/mineral turpentine (1:1) & 40.0 \\
\hline Extracts (organic phase) & 1.0 \\
\hline
\end{tabular}

Table 2. Identification of the paints

\begin{tabular}{cll}
\hline $\begin{array}{c}\text { Identification } \\
\text { P 1 }\end{array}$ & & \multicolumn{1}{c}{ Extracts (organic phase) } \\
\hline P 2 & & $\begin{array}{l}\text { Agelas tubulata } \\
\text { (Demospongia, Agelasidae) }\end{array}$ \\
\hline P 3 & $\begin{array}{l}\text { Myrmekioderma gyroderma } \\
\text { (Demospongia,Heteroxydae) }\end{array}$ \\
\hline P 4 & $\begin{array}{l}\text { Holothuria glaberrima } \\
\text { (Echinodermata, Holothuriidae) }\end{array}$ \\
\hline P 5 & $\begin{array}{l}\text { Oceanapia peltata } \\
\text { (Demospongia, Phloeodictyidae) }\end{array}$ \\
\hline P 6 & $\begin{array}{l}\text { Aplysina lacunosa } \\
\text { (Demospongia, Aplysinidae) }\end{array}$ \\
\hline P 7 & $\begin{array}{l}\text { Neopetrosia (Xestospongia) proxima } \\
\text { (Demospongia, Petrosiidae) }\end{array}$ \\
\hline
\end{tabular}

The anti-fouling paints prepared were applied with a brush on $120 \times 40 \mathrm{~mm}$ sanded acrylic panels previously degreased with toluene. Four coats of paint were applied with a 24-hour drying time between them until obtaining a final dryfilm thickness of $75 \pm 5 \mu \mathrm{m}$. The panels with each type of paint were placed on aluminum racks in series of six and were submerged in the port of Mar del Plata registering the behavior of each formulation after 45 and 90 days. The estimation of attachment of organisms on panels exposed with or without formulations in the sea in function of time was evaluated through a grid as a guide to observe the whole panel given its small size. The panels were removed and observed in the laboratory. Abundance was registered for each species from the macro and microfouling and percentages were estimated.

\section{Results}

The results from the first 45 days demonstrated that significant differences exist regarding the percentage of total coverage between the painted panels and the controls $(\mathrm{p}<0.05)$. The differences were basically due to settlement of the Enteromorpha intestinalis and Ectocarpus sp. algae, colonies of the Bugula sp. briozoo, and to the sandy tubes of the Corophium sp. amphipod. The paints presenting the best antifouling behavior were: P4, P5, P6, and P7. Paint P3, in turn, did not present antifouling effect because the attachment registered did not differ statistically from the controls. However, reduced percentages of attachment of organisms could be noted, especially of the Polydora, Bugula, Ectocarpus, Enteromorpha, and Corophium genera (Fig. 9).

Coincidentally, after 90 days of exposure to the sea significant differences were observed in total coverage between the painted panels and the controls $(\mathrm{p}<0.05)$ (Fig. 10). The species that determined those differences were the same that were registered during the first sampling to which Hydroides elegans was added.

All the paints studied showed antifouling activity, except for P3 (Myrmekioderma gyroderma) whose 
Fig. 9.

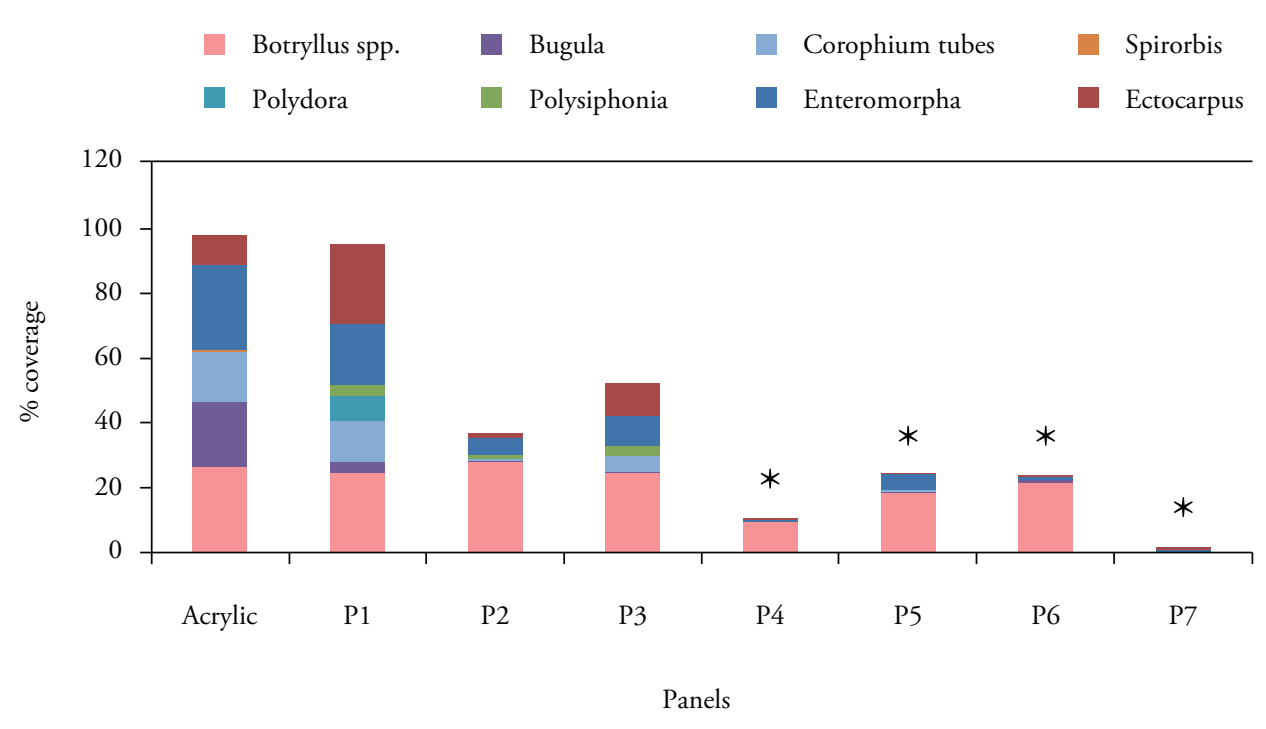

Fig. 10.

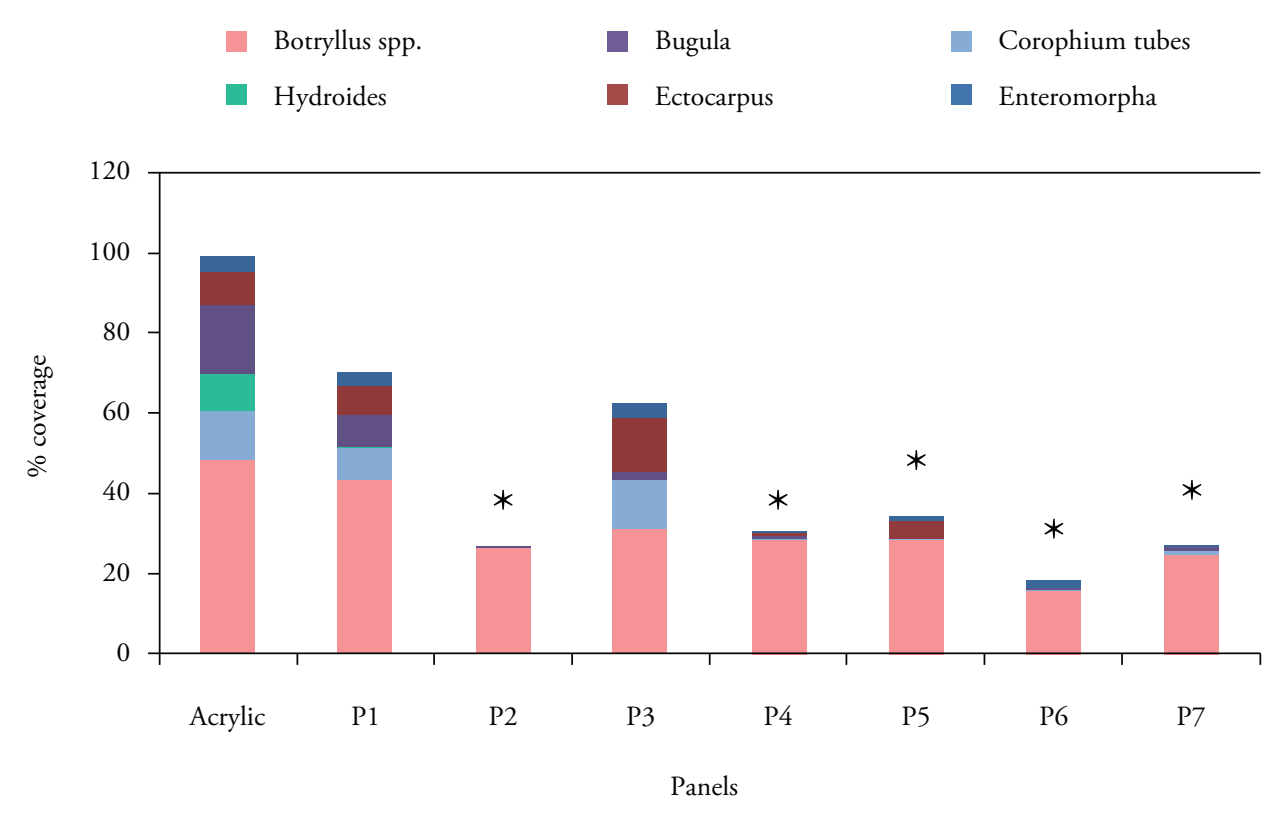

behavior was similar to the controls, as occurred during the first sampling. However, it must be highlighted that the paints containing organic fractions of extracts of Agelas tubulata, Holothuria glaberrima and Neopetrosia proxima presented the best behavior, significantly inhibiting attachment of species present in the fouling from Mar del Plata except for Botryllus sp. $(\mathrm{p}<0.05)$ (Table 3) (Fig. 11). It is worth mentioning that all the organic fractions tested completely inhibited attachment of Hydroides elegans, calcareous tube forming polychaete considered among the most aggressive species of local fouling.

\section{Discussion}

Porifera are among the most studied groups in function of the vast amount of secondary metabolites they produce and that they represent 
Table 3. Antifouling activity of extracts on organisms from biofouling

\begin{tabular}{lccccccc}
\hline \multicolumn{1}{c}{ Components } \\
\begin{tabular}{l} 
Enteromorpha \\
\hline Ectocarpus
\end{tabular}
\end{tabular} \begin{tabular}{cccccccc}
$\mathbf{P}_{1}$ & $\mathbf{P}_{2}$ & $\mathbf{P}_{3}$ & $\mathbf{P}_{4}$ & $\mathbf{P}_{5}$ & $\mathbf{P}_{6}$ & $\mathbf{P}_{7}$ \\
\hline $\begin{array}{l}\text { Bugula } \\
\text { Hydroides }\end{array}$ & + & - & + & + & - & + \\
\hline $\begin{array}{l}\text { Corophium tubes } \\
\text { Botryllus spp. }\end{array}$ & + & + & - & + & - & + & + \\
\hline
\end{tabular}

(+) Positive antifouling activity; (-) negative antifouling activity

an important source of new structures. In this sense, the biggest flow of information on the theme corresponds to this group $(33 \%$ of the articles reported), followed by chordates (8\%), and echinoderms (5\%). The number of compounds isolated from these phyla is 6668 for sponges, 1047 for echinoderms, and 977 for chordates (Blunt et al., 2008).

The most common biogenesis routes of secondary metabolites in sponges from the Demospongiae class (group to which the sponges studied in this group belong) are isoprenoids (50\%), amino acids (25\%), and acetogenins (22\%) (Harper et al., 2001). These metabolites present diverse biological activities like, for example, anti-predator and anti-epibiotic (Becerro et al., 2003; Tsoukatou et al., 2007; Hellio et al., 2005; Clavico et al., 2006;
Thakur and Anil, 2000; Harper et al., 2001; Faulkner, 2002; Blunt et al., 2004).

Also, studies carried out on isolating and identifying natural products extracted from echinoderms have focused fundamentally on sea cucumbers that have shown antifungal, antiviral, and antitumor activity (De Marino et al., 1997; Bryan et al., 1996; Haug et al., 2002; Bryan et al., 1992; Villasin and Pomory, 2000; Hua et al., 2009); in some species like Holothuria leucospilota, it was proven that compounds extracted from their tissues avoided development of biofilms formed by diatoms (Moshake et al., 1994; Gonsalves, 1997).

The huge potential of marine organisms as producers of secondary metabolites remains evident in this work, given that of six species evaluated five presented antifouling activity. More so, if we bear in mind that only the organic fraction of the extracts has been used, it could be assumed that bioactive metabolites could be present in the aqueous fraction and even synergic interactions among metabolites from both fractions that until now have not been contemplated. This point of view does not dismiss, then, that the Myrmekioderma gyroderma sponge, which in this focused work did not show antifouling activity, could be of use.

Due to the excellent results obtained in this series of experiences, it would be of interest to continue with these types of studies, conducting immersion tests with painted panels for more prolonged

Fig. 11.
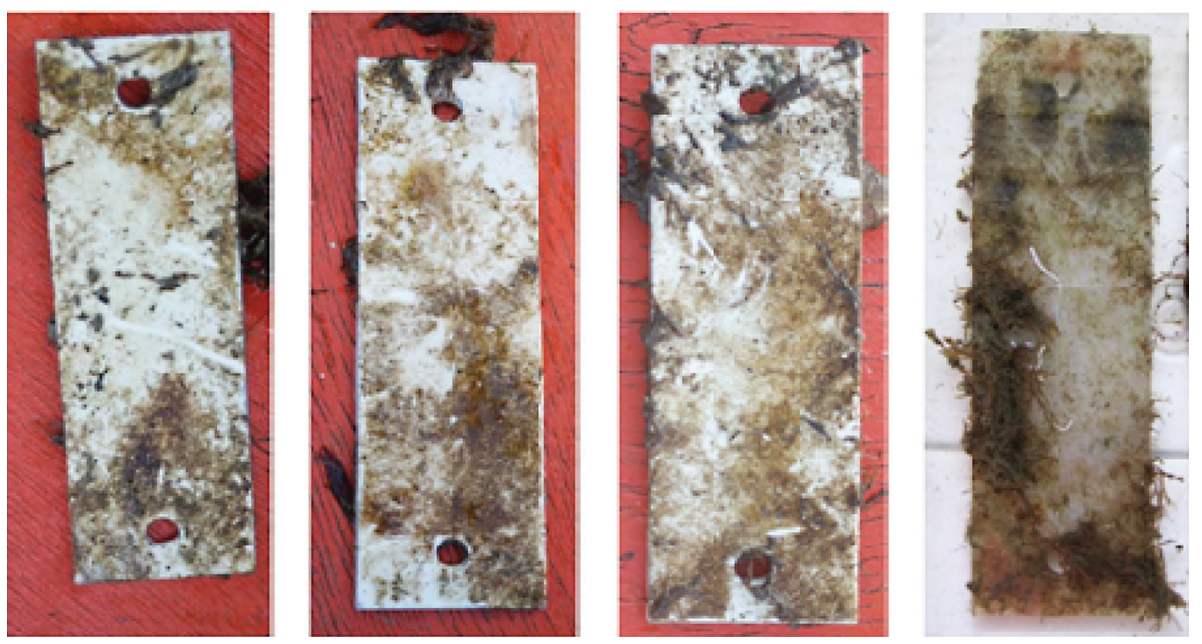
periods to verify the effect of the extracts on other species present during distinct times of the year. Combinations of extracts should also be studied in the laboratory and at sea to detect synergic effects to maximize the antifouling activity.

It is also transcendental to conduct bio-guided tests to establish what molecule or molecules from the organic fraction of the extracts are responsible for this activity and, thus, offer a concrete alternative for their use, by obtaining the product through chemical synthesis or through organism or tissue cultures.

\section{Conclusions}

1. All the extracts included in anti-fouling paints of soluble matrix showed antifouling activity, except for those from Myrmekioderma gyroderma whose behavior was similar to the controls.

2. The best antifouling behavior was presented by paints containing the organic fractions of Agelas tubulata, Holothuria glaberrima, and Neopetrosia proxima extracts.

3. All the extracts tested completely inhibited attachment of Hydroides elegans, calcareous tube forming polychaete considered among the most aggressive species of local fouling.

\section{Bibliography}

ABARZUA, S. and S. JAKUBOWSKI. 1995. Biotechnological investigation for the prevention of biofouling: I. Biological and biochemical principles for the prevention of biofouling. Mar. Ecol. Prog. Ser. 123: 301-312 pp.

ALCOLADO, P.M. 1984. Nuevas especies de esponjas encontradas en Cuba. Poeyana. 271: 1-22 pp.

BECERRO, M.; THACKER, R.; TURON, X.; URIZ, M. AND PAUL, V. (2003). Biogeography of sponge chemical ecology: comparison of tropical and temperate defences.
Oecologia, 135, 91-101.

BELLAS, J. 2005, Toxicity assessment of the antifouling compound zinc pyrithione using early developmental stages of the ascidian Ciona intestinalis. Biofouling. 21: 289-296 pp.

BERGQUIST, P.R. AND S.D.C. COOK. 2002. Family Aplysinidae, en: Hooper, J.N.A. y R.W.M. van Soest (eds.). Systema Porifera: a guide to the classification of sponges. Kluwer Academic/Plenum Publishers, New York. 1082-1085 pp.

BETTIN, C., J. OEHLMANN and E. STROBEN. 1996. TBT-induced imposex in marine neogastropods is mediated by an increasing androgen level. Helgoland Mar. Res. 50 (3): 299-317 pp.

BLUNT, J.; COPP, B.; MUNRO, M.; NORTHCOTE, P. and PRINSEP, M. (2004). Marine natural products. Nat. Prod. Rep. 21, $1-49$.

BLUNT, J.W., B.R. COPP, W.P. HU, M. MUNRO, P.T. NORTHCOTE and M.R Prinsep. 2008. Marine natural products. Natural Products Report. 25: 35-94 pp.

BRYAN, P.; MCCLINTOCK, J.;MARION, K.; WATTS, S. and HOPKINS, T. (1992). Feeding deterrence and chemical defense in echinoderm body wall tissues from the Northern gulf of Mexico. Amer. Zool,, 32, 100.

BRYAN, P.; RITTSCHOF, D. and MC CLINTOCK, J. (1996). Bioactivity of echinoderm ethanolic body-wall extracts: An assessment of marine bacterial attachment and macorinverebrate larval settlement. J. Exp. Mar. Biol. Ecol., 196, 79-96.

CALLOW, M.E. and J.A. CALLOW. 2003. Some New Insights into Marine Fouling. World Super Yacht. 1: 34-39 pp.

CAPRARI, J. y C. LECOT. 2001. El control 
de bivalvos invasores Limnoperna fortunei (Dunker, 1857) en la Central Hidroeléctrica Yacyretá mediante pinturas. Actas Seminario Internacional sobre Gestión Ambiental e Hidroelectricidad, Salto Grande. 24 p.

CASTELLANOS, L. 2007. Metabólitos mayoritarios de las esponjas excavadoras Cliona delitrix y Cliona tenuis, y su papel como aleloquimicos en la competencia por espacio con corales hermatípicos. Tesis de doctorado en Ciencias Química. Universidad Nacional de Colombia, Facultad de Ciencias, Posgrado en Química. 211 p.

CAYCEDO, I.E., 1978. Holothurioidea (Echinodermata) de aguas someras en la costa norte de Colombia. An. Inst. Inv. Mar. Punta Betín. 10: 149-198 pp.

CHAMBERS, L.D., K.R. STOKES, F.C. WALSH, y R.J. WOOD. 2006. Modern approaches to marine antifouling coatings. Surf. Coat. Tech. 201 (6), 3642-3652 pp.

CLARE, A. 1996. Marine natural product antifoulants: status and potential. Biofouling. 9: 211-229 pp.

CLARE, A.S., D. RITTSCHOF, D.J. GERHART y J. MAKI. 1992. Molecular approaches to nontoxic antifouling. Invert. Reprod. Dev. 22: 67-76 pp.

CLAVICO, E.; MURICY, G.; DA GAMA, B.; BATISTA, D.; VENTURA, C. and PEREIRA, R. (2006). Ecological roles of natural products from the marine sponge Geodia corticostylifera. Mar. Biol., 148, 479488.

COLLIN, R., M.C. DIAZ, J.L. NORENBURG, R.M. ROCHA, J.A. SANCHEZ, A. SCHULZ, M.L. SCHWARTZ and A. VALDES. 2005. Photographic identification guide to some common marine invertebrates of Bocas Del Toro, Panama. Caribb. J. Sci. 41 (3): 638-707 pp. da GAMA. A., R. PEREIRA, A. CARVALHO, R. COUTINHO y Y. YONESHIGUEVALENTIN. 2002. The effect of seaweed secondary metabloites on biofouling. Biofouling. 18: 13-20 pp.

DAVIS, A. and A. WRIGHT. 1989. Interspecific differences in fouling of two congeneric ascidians (Eudistoma olivaceum and E. capsulatum). Is surface acidity an effective defense? Mar. Biol. 102: 491-497 pp.

DESQUEYROUX-FAÚNDEZ, R. y C. VALENTINE. 2002a. Family Petrosiidae, en: Hooper, J.N.A. y R.W.M. van Soest (eds.), Systema Porifera: a guide to the classification of sponges. Kluwer Academic/Plenum Publishers, New York. 906-917 pp.

DESQUEYROUX-FAÚNDEZ, R. $\mathrm{y}$ C. VALENTINE. 2002b. Family Phloeodictyidae, en: Hooper, J.N.A. y R.W.M. van Soest (eds.), Systema Porifera: a guide to the classification of sponges. Kluwer Academic/Plenum Publishers, New York. 893-905 pp.

DE MARINO,S.; IORIZZI, M.; ZOLLO, F.; MINALE, L.; AMSDLER, C.; BAKER, B.; MCCLINTOCK, J. (1997). Isolation, structure elucidation, and biological activity of the steroid oligoglycosides and polyhydroxysteroids from the Antarctic starfish Acodontaster conspicuous. J. Nat. Prod., 60, 959-966.

FAULKNER, D. (2002). Marine natural products. Nat. Prod. Rep., 19, 1-48.

FERRARO, M.V., A.S. FENOCCHIO, M.S. MANTOVANI, C. DE OLIVEIRA RIBEIRO y M.M. CESTARI. 2004. Mutagenic effects of tributyltin and inorganic lead (Pb II) on the fish H. malabaricus as evaluated using the comet assay and the piscine micronucleus and chromosome aberration tests. Genet. Mol. Biol. 27: 103-107 pp.

GIÚDICE, C., J. BENITEZ, V. RASCIO y M. 
PRESTA. 1980. Study of variables which affect dispersion of antifouling paints in ball mills. Journal Oil Colour Chemistry Association. 63 (4): $153 \mathrm{p}$.

GONSALVES, C. (1997). Effect of holothurian and zoanthid extract on growth of some bacterial and diatom species.. J. Ind. Mar. Sci., 26, 376-379.

HARDER, T. 2009. Marine epibiosis: concepts, ecological consequences and host defence. En: Marine and industrial biofouling. Springer series on biofilms. 4 (II): 219-231 pp.

HARPER, M.K., T.S. BUGNI, B.R. COPP, R.D. JAMES, B.S. LINDSAY, A.D. RICHARDSON, P.C. SCHNABEL, D. TASDEMIR, R.M. VAN WAGONER, S.M.VERBITSKI y C.M. IRELAND. 2001. Introduction to the chemical ecology of marine natural products, en: McClintock, J.B. y B.J. Baker (eds.). Marine Chemical Ecology. CRC Marine Science Series. 3-69 pp.

HAUG, T.; KJUUL, A.; STYRVOLD, O.; SANDSDALEN, E.; OLSEN, $M$. and STENSVÅG, K. (2002). Antibacterial activity in Strongylocentrotus droebachiensis (Echinoidea), Cucumaria frondosa (Holothuroidea), and Asterias rubens (Asteroidea). J. Invert. Pathol. 81, 94-102.

HELLIO, C.; TSOUKATOU, M.; MARÉCHAL, J.; ALDRED, N.; BEAUPOIL, C.; CLARE, A.; VAGIAS, C. and ROUSSIS, V. (2005). Inhibitory effects of Mediterranean sponge extracts and metabolites on larval settlement of the barnacle Balanus amphitrite. Mar. Biotechnol., 7, 297-305.

HENDLER, G., J.E. MILLER, D.L. PAWSON and P.M. KIER. 1995. Sea stars sea urchins and allies: Echinoderms of Florida and the Caribbean. Smithsonian Institution, Washington. 392 p.

HOOPER, J.N.A., 2002. Family Desmoxyidae, en: Hooper, J.N.A. y R.W.M. van Soest (eds.),
Systema Porifera: a guide to the classification of sponges. Kluwer Academic/Plenum Publishers, New York. 755-772 pp.

HOOPER, J.N.A. y R.W.M. VAN SOEST. 2002. Systema Porifera: a guide to the classification of sponges: Volume 1: Introductions and Demospongiae. Springer. $1810 \mathrm{p}$.

HUA HAN, YANG-HUA YI, LING LI, BAOSHU LIU, MING-PING LA, HONG-WEI ZHANG (2009). Antifungal active triterpene glycosides from sea cucumber Holothuria scabra. Acta Pharmaceutica Sinica, 44 (6), 620-624.

IMO - International Maritime Organization, 2002. Antifouling Systems. Londres. 31 p.

JHA R.K. Y X. ZI-RONG. 2004, Biomedical compounds from marine organisms. Marin Drugs. 2: 123-146 pp.

KONSTANTINOU, I. and T. ALBANIS. 2004. Worldwide occurrence and effects of antifouling paint booster biocides in the aquatic environment. Environment International, 30: 235-248 pp.

LEHNERT, H. y R.W.M. VAN SOEST. 1996. North Jamaican deep fore-reef sponges. Beaufortia. 46 (4): 53-81 pp.

LEWIS, J.B., 1960. The fauna of rocky shores of Barbados, West Indies. Can. J. Zoolog. 38: 391-435 pp.

MARTÍNEZ, I., M. FERRER, A. HERNANDO, R. FERNÁNDEZ-ALBA, F. MARCE y D. BARCELÓ. 2001. Occurrence of antifouling biocides in the Spanish Mediterranean marine environment. Environ. Technol. 2: 543-553 pp.

MILLE, S.R. 2008. Invertebrados. Instituto Politécnico Nacional, México. 662 p.

MILOSLAVICH, P., J.M. DÍAZ, E. KLEIN, J.J. ALVARADO, C. DÍAZ, J. GOBIN, E. 
ESCOBAR-BRIONES, J.J. CRUZ-MOTTA, E. WEIL, J. CORTÉS, A.C. BASTIDAS, R. ROBERTSON, F. ZAPATA, A. MARTÍN, J. CASTILLO, A. KAZANDJIAN y M. ORTIZ. 2010. Marine biodiversity in the Caribbean: Regional estimates and distribution patterns. PloS ONE. 5 (8): 1-25 pp.

MOSHAKE, S.; GARG, A.; ANIL, A. AND WAGH, A. (1994). Growth inhibition of periphytic diatoms of methanol extract of sponges and holothurians. Ind. J. Mar Sci., 23, 57-58.

OMAE, I. 2003. General aspects of tin-free antifouling paints. Chem. Rev. 103: 34313448 pp.

PAWLIK, J. 1992. Chemical ecology of the settlement of benthic marine invertebrates. Oceanogr. Mar. Biol. Annu. Rev. 30: 548-551 pp.

PAWLIK, J.R. 2011. The chemical ecology of sponges on Caribbean reefs: Natural products shape natural systems. BioScience. 61 (11): 888-898 pp.

PEREIRA, W., T. WADE, F. HOSTETTLER y F. PARCHASO. 1999. Accumulation of butyltins in sediments and lipid tissues of the Asian clam, Potamocorbula amurensis, near mare island naval shipyard, San Francisco Bay. Mar. Pollut. Bull., 38: 1005-1010 pp.

POMPONI, S.A. 1999. The bioprocesstechnological potential of the sea. Journal of Biotechnology. 70: 5-13 pp.

RAILKIN, A.I., 2003. Marine Biofouling: Colonization Processes and Defenses, primera edición. CRC Press. 303 p.

RAO, D. J. WEBB, C. HOLSTROM, R. CASE, A. LOW, P. STEINBERG y S. KJELLEBERG. 2007. Low densities of epiphytic bacteria from the marine alga Ulva australis inhibit settlement of fouling organisms. Appl. Environ. Microbiol. 73: 7844-7852 pp.
RASCIO, V., W. BRUZZONI, R. BASTIDA y E. ROZADOS. 1977. Protección de superficies metálicas. Serie III - Manuales Científicos, No 1, LEMIT. $454 \mathrm{p}$.

RASCIO, V., C. GIÚDICE y B. DEL AMO. 1988. Research and development of soluble matrix antifouling paints for ships, offshore platforms, and power stations. A review. Corros. Rev. 8 (1-2): 87-153 pp.

REITSEMA, T. 2008. Antifouling Biocides in Perth Coastal Waters: A Snapshot at selected areas of vessel activity. Water science technical series. Report no WST 1. 48 p.

THAKUR and ANIL, (2000). Antibacterial activity of the sponge Ircinia ramosa: Importance of its surface-associated bacteria. J. Chem. Ecol.., 26, 57-71.

TSOUKATOU, M.; MARÉCHAL, J.; HELLIO, C.; NOVAKOVIC, I.; TUFEGDZIC, S.; SLADIC, D.; GASIC, M.; CLARE, A.; VAGIAS, C. and ROUSSIS, V. (2007). Evaluation of the activity of the sponge metabolites avarol and avarone and their synthetic derivatives against fouling micro- and macroorganisms. Molecules, 12, 1022-1034.

VILLASIN, J. and POMORY, C. (2000). Antibacterial activity of extracts from the body wall of Parastichopus parvimensis (Echinodermata: Holothuroidea). Fish. Shellfish Immunol., 10, 465-467.

VOULVOULIS, N., M. SCRIMSHAW y J. LESTER. 1999. Appl. Organometall. Chem. 13: $135-143 \mathrm{pp}$.

VOULVOULIS, N., M. SCRIMSHAW y J. LESTER. 2000. Occurrence of four biocides utilised in antifouling paints, as alternatives to organotin compounds, in waters and sediments of a commercial estuary in the UK. Mar. Poll. Bull. 40: 938-946 pp.

VOULVOULIS, N., M. SCRIMSHAW y J. LESTER. 2002. Comparative environmental 
assessment of biocides used in antifouling paints. Chemosphere, 47: 789-795 pp.

VROLIJK, N., N. TARGETT, R. BAIER, R. y A. MEYER. 1990. Surface characterization of two gorgonian coral species: implications for a natural antifouling defense. Biofouling. 2: 39$54 \mathrm{pp}$.

WAHL, M. 1989. Marine epibiosis. I. Fouling and antifouling: some basic aspects. Mar. EcolProg. Ser. 58 (1): 175-189 pp.

WU, J., P.J. MENG, M.Y. LIU, Y.W. CHIU y L.L. LIU. 2010. A high incidence of imposex in pomacea apple snails in Taiwan: A Decade after Triphenyltin Was Banned. Zool. Stud. 49 (1): 85-93 pp.

YEBRA, D.M., S. KIIL y K. DAM-JOHANSEN. 2004. Antifouling technology: past, present and future steps towards efficient and environmentally friendly antifouling coatings. Prog. Org. Coat. 50 (2): 75-104 pp.

ZEA, S. 1987. Esponjas del Caribe colombiano., Primera edición. Catalogo Científico, Bogotá. 286 p. 